\title{
Plasma and blood volume studies in malnourished Iraqi children
}

\author{
By A. SHAKIR, A. Y. HINDAWI AND A. L. EL-BEDRI \\ Department of Medicine and Department of Surgery, College of Medicine, \\ University of Baghdad, Iraq \\ (Received 9 October 1970-Accepted I8 Fanuary 1971)
}

\begin{abstract}
I. The plasma and blood volumes of twenty-eight Iraqi children were measured. Twentyfour of them were malnourished in varying degrees and four were normal children who acted as controls. None of the children was anaemic.

2. There was an increase in the plasma and blood volumes per unit body-weight correlating with the degree of malnourishment $(P<0.001)$.

3. There was little variation in the values for plasma and blood volumes when calculated per unit body length; the values were less constant when calculated per unit body surface.

4. The effect of age on the plasma and blood volumes per unit body-weight was less than the effect of the degree of malnutrition.

5. There was no correlation between the plasma volume of malnourished children and their corrected venous haematocrit, if children with severe anaemia were excluded.
\end{abstract}

Malnutrition is common among children in Iraq (Zaki, 1968). Several workers have reported on the increased plasma volume occurring in malnutrition (Gollan, 1948; Gómez, Ramos-Galván, Cravioto, Moñóz \& Bienvenú, I950; Cohen \& Hansen, 1962; Picou, I963; Alleyne, I966). Alleyne (1966) showed a correlation between the plasma volume and the body-weight deficit in malnourished Jamaican children. However, the increase in the plasma volume in previous reports could have been due partly to the effect of anaemia in some of the children studied. In this report we excluded any malnourished child with severe anaemia. The relation of the plasma and blood volumes to body-weight, body length and body surface area was investigated.

\section{EXPERIMENTAL}

Twenty-eight children from the Children's Welfare Hospital in Baghdad were studied. They were sixteen boys and twelve girls, and their ages ranged from $\mathrm{I} \cdot 5$ to 48 months. Twenty-four children were considered to be malnourished in varying degrees. The grading of the nutritional state was based on their percentage expected weight for length, using the Harvard standards of Stuart \& Stevenson, quoted by Jelliffe (I966). Four children who had a grading of above $100 \%$ for their expected weight for length, and who were in hospital after recovering from a minor ailment, were included as normal controls. Any child with a corrected venous haematocrit less than $25 \%$ was excluded from the study. All the children were investigated on the morning before the $4^{\text {th }}$ day of their admission to hospital, and were given Lugol's iodine to block the thyroid gland. The dose of Lugol's iodine was 5 drops daily for $3 \mathrm{~d}$, starting on the morning of the test. 
The plasma volume was determined with ${ }^{125}$ I-labelled human serum albumin (Radiochemical Centre, Amersham, Bucks). The dose of $2-5 \mu \mathrm{Ci}{ }^{125} \mathrm{I}$ in I $\mathrm{ml}$ was injected intravenously, and a blood sample was withdrawn ro min later. A standard solution was also prepared by adding I ml labelled albumin to $5 \mathrm{ml} 20 \%$ sodium hydroxide solution containing a drop of strong potassium iodide solution, and made up to volume with water to produce a $I$ in 100 dilution (Veall \& Vetter, 1958). The activity of the blood sample after haemolysis with saponin was compared with that of the standard by taking $3 \mathrm{ml}$ of each and counting the samples in a well-type scintillation counter. The haematocrit was measured in a Hawksley micro-haematocrit centrifuge with capillary tubes and the reading was multiplied by the factor 0.9 I to correct for trapped plasma (Chaplin \& Mollison, 1952). The plasma volume was calculated according to the formula:

$$
\text { Plasma volume }(\mathrm{ml})=\frac{S \times D \times I}{B \times 100}(100-H),
$$

where $S$ is the activity of the standard, $D$ the dilution factor (Ioo), $I$ the volume of solution injected (ml), $B$ the activity of the blood sample, and $H$ the venous haematocrit corrected for trapped plasma. The blood volume was then calculated from the plasma volume as follows:

$$
\text { Blood volume }(\mathrm{ml})=\frac{\text { plasma volume } \times 100}{100-W B H},
$$

where $W B H$ (whole body haematocrit) = corrected venous haematocrit $(H) \times 0.91$ (Chaplin, Mollison \& Vetter, 1953).

In ten samples the blood volume was measured with the Pitman blood volume computer as well as by the above-mentioned method, and the results were in agreement.

\section{RESULTS}

Table I shows the total plasma volume and blood volume for all the subjects, arranged according to the degree of body-weight deficit expressed as percentage expected weight for length. There was a significant correlation between the plasma volume per kg body-weight and the percentage expected weight for length in normal and malnourished children $(r=-0.73, P<0.001)$ (Fig. I). The blood volume per $\mathrm{kg}$ was also significantly correlated with percentage expected weight for length $(r=-0.70, P<0.001)$.

The increase in the plasma volume per unit body-weight corresponded closely to the grade of malnutrition, as expressed by the weight deficit $(P<0.001)$ (Table 2$)$. On the other hand, the values for the plasma volume per unit body length were more or less constant over different grades of malnutrition, and the values per unit surface area were, as expected, less constant than those related to length. The values for blood volume showed the same pattern as the plasma volume.

Fig. 2 shows the relation of the plasma volume per $\mathrm{kg}$ body-weight to the corrected venous haematocrit. There was no significant correlation between the plasma volume 
Vol. 26

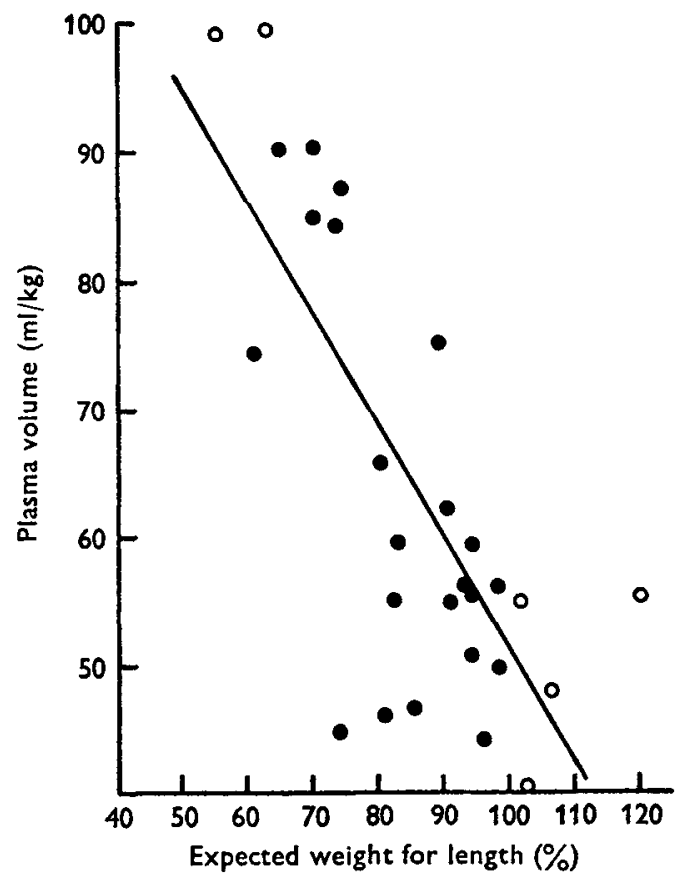

Fig. I. Plasma volume in malnourished and normal children related to their percentage expected weight for length $(y=\bar{y}-0.869(x-\bar{x})), r=-0.73, P<0.001 .0$, normal children; , malnourished children.

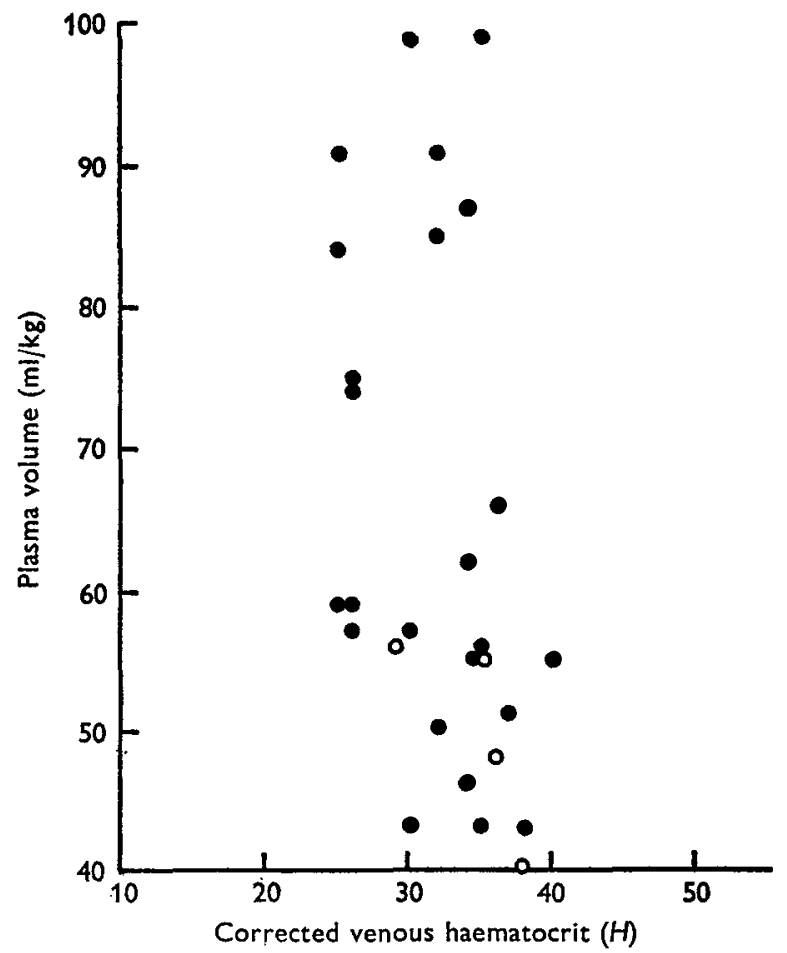

Fig. 2. Relation of plasma volume to corrected venous haematocrit $(H)$ in malnourished and normal children, $r=-0.07 .0$, normal children; $\odot$, malnourished children. 
Table I. Total plasma and blood volume in the children studied, grouped according to the degree of weight deficit

\begin{tabular}{|c|c|c|c|c|c|c|c|c|}
\hline $\begin{array}{l}\text { Child } \\
\text { no. }\end{array}$ & $\begin{array}{c}\text { Age } \\
\text { (months) }\end{array}$ & Sex & $\begin{array}{l}\text { Body- } \\
\text { weight } \\
\text { (kg) }\end{array}$ & $\begin{array}{l}\text { Body } \\
\text { length } \\
(\mathrm{cm})\end{array}$ & $\begin{array}{l}\text { Percentage } \\
\text { expected } \\
\text { weight } \\
\text { for length }\end{array}$ & $\begin{array}{c}\text { Corrected } \\
\text { venous } \\
\text { haematocrit } \\
(\%)\end{array}$ & $\begin{array}{l}\text { Total } \\
\text { plasma } \\
\text { volume } \\
(\mathrm{ml})\end{array}$ & $\begin{array}{c}\text { Total } \\
\text { blood } \\
\text { volume } \\
(\mathrm{ml})\end{array}$ \\
\hline 15 & r 5 & $?$ & $4 \cdot 46$ & 68 & 55 & 35 & $44 \mathrm{I}$ & 650 \\
\hline 45 & 10 & $\delta$ & 3.95 & 63 & 61 & 26 & $29 \mathrm{I}$ & 383 \\
\hline 20 & $4 \cdot 5$ & $q$ & $3 \cdot 21$ & 57 & 63 & 30 & 316 & 433 \\
\hline 34 & 8 & q & 3.70 & 60 & 65 & 25 & 337 & 439 \\
\hline 19 & $I \cdot 5$ & $0^{*}$ & $2 \cdot 64$ & $5^{I}$ & 70 & 32 & 242 & 340 \\
\hline 12 & 14 & $q$ & $3 \cdot 83$ & 59 & 70 & 32 & 326 & 460 \\
\hline 13 & I 2 & $\sigma^{x}$ & 5.71 & 67 & 73 & 25 & $4^{8} 3$ & 627 \\
\hline 8 & 8 & $0^{x}$ & 5.79 & 66 & 74 & 38 & $25^{2}$ & 388 \\
\hline $46^{*}$ & 24 & q & $6 \cdot 20$ & 69 & 74 & 34 & 543 & 787 \\
\hline 9 & 18 & 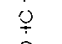 & $7 \cdot 90$ & 74 & 80 & 36 & 521 & 777 \\
\hline 5 & 12 & 9 & 5.91 & 65 & $8 I$ & 34 & 268 & 389 \\
\hline 16 & 28 & 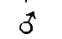 & $9 \cdot 69$ & 84 & 82 & 40 & 536 & 817 \\
\hline 42 & 22 & $\sigma$ & $8 \cdot 19$ & 74 & 83 & 25 & 488 & 609 \\
\hline 44 & 36 & Q & 10.00 & 84 & 85 & 30 & 422 & 578 \\
\hline $30^{\circ}$ & 30 & 9 & 9.85 & $8 \mathrm{I}$ & 88 & 26 & 743 & 977 \\
\hline 17 & 23 & $\delta$ & $9 \cdot 80$ & 79 & 90 & 34 & 603 & 874 \\
\hline 33 & $7 \cdot 5$ & $\delta$ & $8 \cdot 36$ & 71 & 91 & 35 & $46 I$ & 679 \\
\hline $3^{8}$ & 18 & 0 & $8 \cdot 20$ & 70 & 93 & 30 & 467 & 640 \\
\hline 3 & 32 & $\delta$ & 12.50 & $9 \mathrm{I}$ & 94 & 37 & 639 & 968 \\
\hline 10 & 15 & $\overrightarrow{0}$ & 9.40 & 74 & 94 & 26 & 560 & 737 \\
\hline 28 & I I & 0 & $7 \cdot 30$ & 67 & 94 & 35 & 410 & 603 \\
\hline 4 & 48 & 우 & 14.00 & 96 & 96 & 35 & 597 & 878 \\
\hline I & 10 & $\overrightarrow{0}$ & $8 \cdot 60$ & 70 & 98 & 32 & 432 & 608 \\
\hline 43 & 15 & 0 & 10.00 & 76 & 98 & 26 & 570 & 750 \\
\hline $35 t$ & 5 & 우 & 5.40 & 58 & IOI & 35 & 296 & 435 \\
\hline $7 \dagger$ & 14 & 0 & $9 \cdot 35$ & 72 & 102 & 38 & 375 & 576 \\
\hline $2 t$ & 6 & $\hat{\jmath}$ & $7 \cdot 80$ & 65 & 106 & 36 & 373 & 557 \\
\hline 3 It & 9 & $j$ & 10.80 & 71 & 120 & 29 & 609 & 824 \\
\hline
\end{tabular}

Table 2. Mean values and standard deviations for plasma volume and blood volume of the children, calculated per unit body-weight $(\mathrm{kg})$, per unit body length $(\mathrm{cm})$ and per unit body surface area $\left(\mathrm{m}^{2}\right)$ and grouped according to the degree of weight deficit

\begin{tabular}{|c|c|c|c|c|c|c|c|}
\hline $\begin{array}{c}\text { State of } \\
\text { nutrition } \\
\text { (\% expected } \\
\text { weight for } \\
\text { length) }\end{array}$ & $\begin{array}{l}\text { No. of } \\
\text { children }\end{array}$ & $\begin{array}{l}\text { Plasma } \\
\text { volume } \\
(\mathrm{ml} / \mathrm{kg})\end{array}$ & $\begin{array}{l}\text { Blood } \\
\text { volume } \\
(\mathrm{ml} / \mathrm{kg})\end{array}$ & $\begin{array}{l}\text { Plasma } \\
\text { volume } \\
(\mathrm{ml} / \mathrm{cm})\end{array}$ & $\begin{array}{c}\text { Blood } \\
\text { volume } \\
(\mathrm{ml} / \mathrm{cm})\end{array}$ & $\begin{array}{l}\text { Plasma } \\
\text { volume } \\
\left(\mathrm{ml} / \mathrm{m}^{2}\right)\end{array}$ & $\begin{array}{c}\text { Blood } \\
\text { volume } \\
\left(\mathrm{ml} / \mathrm{m}^{2}\right)\end{array}$ \\
\hline $60-70$ & 6 & $\begin{array}{l}89 \cdot 8 \\
\pm 8 \cdot 7^{* * *}\end{array}$ & $\begin{array}{l}122 \cdot 6 \\
\pm 17 \cdot 4 * *\end{array}$ & $\begin{array}{r}5.4 \\
\pm 0.4\end{array}$ & $\begin{array}{r}7.5 \\
\pm 1.0\end{array}$ & $\begin{array}{r}1334 \\
\pm 140\end{array}$ & $\begin{array}{r}1845 \\
\pm 224\end{array}$ \\
\hline $70-80$ & 4 & $\begin{array}{r}70 \cdot 0 \\
+20 \cdot 8\end{array}$ & $\begin{array}{c}100 \cdot 2 \\
\pm 25.2\end{array}$ & $\begin{array}{r}6.5 \\
+1.7\end{array}$ & $\begin{array}{r}9.2 \\
+24\end{array}$ & $\begin{array}{r}1317 \\
\pm 357\end{array}$ & $\begin{array}{r}1882 \\
\pm 470\end{array}$ \\
\hline $80-90$ & 6 & $\begin{array}{r}56.6 \\
\pm 10.3\end{array}$ & $\begin{array}{r}78 \cdot 3 \\
\pm 15.4\end{array}$ & $\begin{array}{r}6.4 \\
+1.8\end{array}$ & $\begin{array}{r}8.9 \\
\pm 2.4\end{array}$ & $\begin{array}{r}1191 \\
\pm 232\end{array}$ & $\begin{array}{r}1630 \\
\pm 325\end{array}$ \\
\hline $90-100$ & 8 & $\begin{array}{r}53.5 \\
\pm 0.5\end{array}$ & $\begin{array}{r}75.7 \\
\pm 6.5\end{array}$ & $\begin{array}{r}6.7 \\
\pm 0.4\end{array}$ & $\begin{array}{r}9.4 \\
\pm 0.7\end{array}$ & $\begin{array}{r}1176 \\
\pm 106\end{array}$ & $\begin{array}{r}1673 \\
\pm 103\end{array}$ \\
\hline Over roo & $4 t$ & $\begin{array}{r}49.7 \\
\pm 5.8\end{array}$ & $\begin{array}{r}72.5 \\
\pm 7.6\end{array}$ & $\begin{array}{r}5.9 \\
\pm 1.1\end{array}$ & $\begin{array}{r}8.8 \\
+1.8\end{array}$ & $\begin{array}{r}1122 \\
\pm 216\end{array}$ & $\begin{array}{r}1599 \\
+216\end{array}$ \\
\hline
\end{tabular}


in malnourished children and the corrected venous haematocrit, if children with severe anaemia are excluded. The effect of age on the plasma and blood volumes per unit body-weight in malnourished children is shown in Table 3 . Children of the same age had widely varying plasma and blood volumes, depending on their state of nutrition.

Table 3. Effect of age on the plasma and blood volume per unit body-weight $(\mathrm{ml} / \mathrm{kg})$ in malnourished children, grouped according to their degree of weight deficit, and in normal children

\begin{tabular}{|c|c|c|c|c|}
\hline $\begin{array}{l}\text { Age range } \\
\text { (months) }\end{array}$ & $\begin{array}{c}\text { State of } \\
\text { nutrition } \\
(\% \text { expected } \\
\text { weight for } \\
\text { length) }\end{array}$ & $\begin{array}{c}\text { Child } \\
\text { no. }\end{array}$ & $\begin{array}{l}\text { Plasma } \\
\text { volume } \\
(\mathrm{ml} / \mathrm{kg})\end{array}$ & $\begin{array}{l}\text { Blood } \\
\text { volume } \\
(\mathrm{ml} / \mathrm{kg})\end{array}$ \\
\hline \multirow[t]{8}{*}{$3-x \mid$} & $60-70$ & $\begin{array}{l}45 \\
20\end{array}$ & $\begin{array}{l}74 \\
99\end{array}$ & $\begin{array}{r}97 \\
\mathrm{r} 35\end{array}$ \\
\hline & & 34 & $9 \mathrm{I}$ & 119 \\
\hline & & Mean & 88.0 & $117 \cdot 0$ \\
\hline & $90-100$ & $\begin{array}{l}33 \\
28\end{array}$ & $\begin{array}{l}55 \\
56\end{array}$ & $\begin{array}{l}81 \\
83\end{array}$ \\
\hline & & I & 50 & $7 I$ \\
\hline & & Mean & $53 \cdot 6$ & $78 \cdot 3$ \\
\hline & Over roo & $\begin{array}{r}35 \\
2\end{array}$ & $\begin{array}{l}55 \\
48 \\
56\end{array}$ & $\begin{array}{l}81 \\
71 \\
76\end{array}$ \\
\hline & & $\begin{array}{c}3 \mathrm{I} \\
\text { Mean }\end{array}$ & $\begin{array}{l}56 \\
53 \cdot 0\end{array}$ & $\begin{array}{l}76 \\
76 \cdot 0\end{array}$ \\
\hline \multirow[t]{8}{*}{$12-24$} & $70-80$ & $\begin{array}{l}\mathrm{I} 2 \\
\mathrm{I3}\end{array}$ & $\begin{array}{l}85 \\
84\end{array}$ & $\begin{array}{l}\text { I10 } \\
\text { I09 }\end{array}$ \\
\hline & & Mean & $84 \cdot 5$ & 109.5 \\
\hline & $80-90$ & $\begin{array}{l}9 \\
5\end{array}$ & $\begin{array}{l}66 \\
46\end{array}$ & $\begin{array}{l}98 \\
66\end{array}$ \\
\hline & & 42 & 59 & 74 \\
\hline & & Mean & $57 \cdot 0$ & $79 \cdot 3$ \\
\hline & $90-100$ & $\begin{array}{l}38 \\
\text { 10 }\end{array}$ & $\begin{array}{l}57 \\
59\end{array}$ & $\begin{array}{l}78 \\
78\end{array}$ \\
\hline & & 43 & 57 & 75 \\
\hline & & Mean & $57 \cdot 7$ & 77.0 \\
\hline
\end{tabular}

DISCUSSION

The values for plasma volume in normal Iraqi children and in those with mild malnutrition (i.e. children whose percentage expected weight for length is less than $90 \%$ and more than $70 \%$ ) were similar to the results in normal and malnourished children reported by several workers (Cohen \& Hansen, I962; Picou, 1963; Alleyne, I 966). In severely malnourished children (i.e. those whose percentage expected weight for length is less than $70 \%$ ) the values were much higher, but were less than those found by Gómez et al. (1950).

The blood volume followed the same pattern. There was a significant difference 
between the blood volumes of severely malnourished and normal children, as reported by Gómez et al. (1950).

The increased blood volume in our children was not due to anaemia, since all children whose haematocrit was less than $25 \%$ were excluded from the study. In other reports anaemic subjects were not excluded, which probably affected the plasma and blood volumes.

The effect of age on the values for plasma and blood volumes per unit body-weight, as seen in Table 3, was less than that of the state of nutrition.

These results show clearly that in malnourished children the plasma volume and blood volume, although increased in relation to body-weight, bear a constant relationship to height, regardless of the degree of malnutrition. It seems, therefore, that the blood volume, like the brain and the skeleton, represents a system which is, to a large extent, protected from the effects of malnutrition, in contrast to tissues such as muscle and subcutaneous fat, which are greatly reduced in mass. The mechanism by which this constancy is maintained remains to be determined.

The authors would like to thank Professor Wolff, Professor Waterlow and Dr N. Veall, who gave advice and reviewed this manuscript. They are most grateful to Dr Demarchi for the estimation of the venous haematocrit.

\section{REFERENCES}

Alleyne, G. A. O. (I966). Archs Dis. Childh. 41, 3 I3.

Chaplin, H. Jr \& Mollison, P. L. (1952). Blood 7, 1227.

Chaplin, H. Jr, Mollison, P. L. \& Vetter, H. (1953). J. clin. Invest. 32, 1309.

Cohen, S. \& Hansen, J. D. L. (1962). Clin. Sci. 23, 35 I.

Gollan, F. (1948). $\mathcal{F}$. clin. Invest. 27, 352.

Gómez, F., Ramos-Galván, R., Cravioto, J., Moñóz, J. \& Bienvenú, B. (1950). Boln méd. Hosp. infant., Méx. 7,5 I 4 .

Jelliffe, D. B. (1966). Monograph Ser. W.H.O. no. 53, p. 224.

Picou, D. I. M. (1963). Protein metabolism in protein depleted infants. PhD Thesis, University of London.

Veall, N. \& Vetter, H. (1958). Radioisotope Techniques in Clinical Research and Diagnosis p. 225. London: Butterworths.

Zaki, L. A. (1968). F. Fac. Med., Baghdad ro, 64. 